\section{Sukuk: A Veritable Tool For Effective Waqf Fund Management In Nigeria}

Sukuk:

A Veritable

Tool

\author{
Adamu Umar
}

International Institute of Islamic Banking and Finance (IIIBF), Malaysia and Department of Banking and Finance, Bayero University, Kano, Nigeria. aumar.iiibfbuk@buk.edu.ng

\author{
Shehu U.R. Aliyu \\ International Institute of Islamic Banking and Finance, Bayero University, Kano, \\ Nigeria. \\ suarano.eco@buk.edu.ng
}

\begin{abstract}
Since its emergence in the early 2000's, Sukuk has been regarded as the most significant innovation recorded in the Islamic capital market. Sukuk is generally regarded as an equivalent of conventional bond, Sukuk paved way for mobilization of long term Shari'ah compliant funds for equally Shari'ah compliant undertakings. Islamic capital market experts have developed various Shari'ah compliant Sukuk structures, notable among which is Waqf-based Sukuk structure. Viewed as a distinct ethical capitalism and a veritable vehicle for long term financing, Waqf was found to record tremendous impact in all spares of human needs. The paper seeks to unveil how Waqf-based Sukuk could be used to attain effective mobilization as well as management of Waqf assets. It explores the possibility of issuing Waqf-based Sukuk for the development, renovation, reconstruction and modification of Waqf assets in Nigeria. The paper employs a non-experimental, deductive-analytical approach, in its investigation. Evidences show that Waqf-linked Sukuk has been successful in the development of Waqf assets in countries like Indonesia, Singapore and Saudi Arabia. Accordingly, the paper develops a Waqf-based Sukuk (ijarah) framework for fund mobilization for development of Waqf properties in Nigeria. We strongly recommend that both formal and non-formal Waqf institutions in Nigeria should utilize this outlet to effectively develop, deepen and manage their philanthropic activities.
\end{abstract}

Keywords:

Sukuk, Waqf, Fund management, Build operate and transfer (BOT).

\section{INTRODUCTION}

There are a sizable number of assets under different endowments A wqaf (plural of Waqf) in Nigeria which are not being utilized in the most productive manner. Most of such Waqf assets are in the form mosques, Islamiyah schools, houses and shops. Majority were built and donated for hundreds of years and as such the buildings are now dilapidated and therefore need renovations and 
IQTISHADIA

12,1

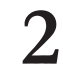

Further, evidence in the literature lament the problem of low capacity or expertise of the Waqf asset administrators (Nazir) in modern knowledge and skills for managing such assets as well as modern sources of financing to develop these assets. On this note, Maghbub and Alhajam (2018) posit that there is lack of good governance and Waqf managements such that, in most cases, are not transparent and accountable to Waqf stakeholders. Moreover, by encouraging the use of these traditional methods for developing Waqf properties, it will give them legal justification to further expropriating and abusing Waqf assets in the name of development.

Consequently, the administration or management of Waqf foundations remains largely traditional with Nazirs sitting on pool of dilapidated, yet scattered assets that hardly maintain themselves but often degenerate over time. Recent advances in the field of Islamic finance have paved way for effective development of these classes of assets through funding from Shari'ah compliant investors. Literature is replete with a number of financing arrangements like cash Waqf, Waqf shares and Waqf Sukuk.

Against this background, this paper seeks to explore the possibility of developing a Waqf-based Sukuk framework for effective development, renovation, reconstruction and upgrading of existing Waqf assets in Nigeria in the light of experiences from other jurisdictions. The paper comprises of five sections. Section 1 constitutes the introduction while section 2 presents a review of key concepts and literature on Waqf, Sukuk and the concept of build, operate and transfer (BOT). Section 3 reviews successful application of Waqf-based Sukuk in Singapore and Saudi Arabia, section 4 outlines the 
Waqf-based Sukuk framework of the paper and finally, section 5 presents conclusion and recommendations.

\section{REVIEW OF CONCEPTS}

\section{The Concept of Waqf}

Waqf, in the Arabic language, literally means to stop, contain or preserve. Conceptually, Waqf refers to charitable endowments. It is a voluntary and irrevocable dedication of one's wealth, either in cash or kind, and its disbursement is dedicated for Shari'ah compliant projects that are beneficial (Elasrag, 2017). It generally refers to holding and preserving a certain philanthropy-sadaqah (charity) with the intention prohibiting any use or disposition of the property outside the specific purposes to which the property is dedicated, in such a way that it cannot be bequeathed or sold. It transfers wealth and changes property rights from private to public.

Waqf has three fundamental characteristics. First, Waqf should be irrevocable. Majority of scholars agree that a property declared as Waqf cannot be revoked by the declarant or his heirs. Secondly, it should be perpetual once created. Majority of jurists are on this view. This implies that a Waqf property cannot and should not be confiscated by government or individual, this will ensure regular and continual support from the Waqf property towards financing charitable purposes such as mosques, hospitals, orphanages, and schools or any purpose that will improve the welfare of the Muslim community. Finally, a Waqf property or asset should be inalienable once created. This is because the property donated or declared as Waqf has been dedicated for the sake of Allah for some charitable purpose. All jurists agree that Waqf is like a frozen asset and hence, cannot be sold, disposed, mortgaged, gifted, inherited or alienated in any way whatsoever. It can however be given out on a long term lease (Hikr) or be made the subject of a dual lease payment in an effort to develop it.

Waqf has played a crucial role in social welfare and economic development of the Ottoman Empire through the provision of healthcare, education and training facilities for the society. In view of this there is strong need for improving the existing financing and management mechanism of Waqfs (Tahir, Abdul Hamid \& Ismail 2005). Lahsasna (2013) made a strong case for Waqf to be upgraded to a level where they become a sustainable source of funding and are able to generate income on their own, thereby decreasing dependency on third-party donations. The need for Waqf asset to continue existing and providing economic benefit to beneficiaries requires 
IQTISHADIA

12,1

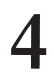

that it should be aligned to an investment product or mechanism which is perpetual in nature where preservation of capital is necessary as is the case with Sukuk (Marzuki et al., 2012). The trend now is towards promoting cash $W a q f$ for management of Waqf assets. Cash Waqf has the potential to serve as capital for the development of idle Waqf land (Anwar \& Isa 2016).

Earlier on Tahir et al. (2005) found that a large number of Waqftrustees (Mutawalis) are not well trained in property and financial management hence, the need for experts in the Islamic financial sector to help manage and offer innovative financial tools like Waqf linked or Social Responsible Investment Sukuk. Ismail et al. (2015) explore the potentials of a sovereign Sukuk linked to Waqf assets for the development of massive local Waqfs that are underdeveloped in Indonesia. The Waqf linked Sukuk issuance is intended for real economic sector development, just like a project based Sukuk. Depending on the investors' preference, the Sukuk can be fine-tuned to serve both commercial and social purposes. Islamic Wealth Management (2015) identifies instruments such as Cash and E-Waqf Fund, Per-square Feet Value Certificate, and Sukuk issuance as some of the ways through which funds can be accumulated for the development of Waqf assets.

\section{Waqf-based Sukuk}

Sukuk is derived from the Arabic word Sak (singular) which has Sukuk as plural which means a certificate or note. Technically Sukuk is an evidence (claim) of ownership. It is a certificate of equal value with part or whole of the ownership of tangible property to obtain products and services in asset ownership and a specific project or a specific investment. The International Islamic Fiqh Academy issued a statement in 1988, defines Sukuk as “Any combination of assets (or the usufruct of such assets) can be represented in the form of written financial instruments which can be sold at a market price provided that the composition of the groups of assets represented by the sukuk consist of a majority of tangible assets". Further, the Accounting and Auditing Organization Islamic Finance Institutions (AAOIFI), defines Sukuk as: "Investment sukuk are certificates of equal value representing undivided shares in ownership of tangible assets, usufructs and services or (in the ownership of) the assets of particular projects or special investment activity, however, this is true after receipt of the value of the sukuk, the closing of subscription and the employment of funds received for the purpose for which the sukuk were issued." 
The general process for issuance Sukuk requires broad three steps: creation of a special purpose vehicle (SPV) to represent the investors, issuance of the certificates and putting them into circulation and securing the cash-flow through the period of the contract from the issuer to the investor. Added to these in the structuring are: the originator of the Sukuk otherwise the obligor and investors who are the Sukuk certificate holders. The SPV often doubles as trustees and managers, coordinating the interests of both parties the obligor and investors (Oubdi and Raghibi (2018).

The structure waqf-based sukuk, does not differ from that of an investment Sukuk except in the objective of the investors. While the objective of an investment Sukuk investor is that of making profit, the holder of Waqfbased Sukuk certificate is driven by desire of deriving maximum reward from the Almighty Allah and His blessings by serving public interest.

There are numerous classes of Waqf assets that are laying idle that could be utilized as underlying assets for the purpose of Sukuk issuance and thereby making it possible to link Sukuk with Waqf in an effort to mobilize long term funding. This particular feature is what attracts attention of experts to turn to the Sukuk for the effective utilization of Waqf assets in addition to other classical contracts such as hikr and ijaratayn. Hikr is one of the modes through which Waqf assets in the form agricultural land or real estate investment can be financed, in Hikr the trustee can lease out the Waqf asset on a long lease at a nominal periodic rent, while in Ijaratayn there are two rent payments, the first is a lump sum paid for financing renovation or maintenance of the property and second is a periodic payment to be made over the period of the rent. The introduction of Sukuk instruments has helped to further accelerate the progress and development of Waqf. A number of Waqf linked Sukuk has already been issued in Singapore, Saudi Arabia and Malaysia with a huge success. These provide an important case study for other countries as well as good experiences to learn from.

Waqf Sukuk can be issued by endowment organizations, relevant government agencies in charge of Zakah and Waqf such as various Zakah and Waqf Foundations that we have in different states of Nigeria. It could also be issued by Islamic banks and charity organizations. The proceeds of the Sukuk can be used either for humanitarian needs with no immediate expected cash returns, or for investments which usually yields returns and can help in developing the endowment organizations on other projects. 
IQTISHADIA

12,1

6

\section{The Concept of Build-Operate-Transfer (BOT)}

Build-operate-transfer is one of the contemporary options used in project financing. It enables client to have access to fund for construction on event of fund insufficiency. It could defined as a financing partnership between a private and government with parties involved receiving concession on design, planning, funding, execution and management of a project (Lekan, Opeyimi \& Olayinka, 2013). The system provides an opportunity for a project to be managed after completion to enable the financiers recover the sum invested in the project. It was developed in response to the need to execute project effectively and to generate funds for high cost projects that became necessary for the government and for which funds are not readily available. In this type of arrangement, private investors undertake the project funding, operates it before transferring it to the government (Chege and Rwelamila, 2000 and Zhang, 2005).

On a typical BOT project, the financier looks primarily to the project as only means of payment in case financing facility is accessed in the project financing; this is usually premised on the credit worthiness assessment of the project at feasibility stage. So also, it involves security assurance, security taken on a typical BOT project is often restricted to the project. BOT mechanism is a complex structure comprising multiple, inter-dependent agreements among various parties. Some of such parties includes: government, private company (concessionaire), lenders (banks), equity investors, contractors, suppliers, operators and financial advisers. Government grants concession to the private sector (concessionaire), through concession agreement. The concessionaire is responsible for design, finance, construction, and operation of the facility. According to Akintoye, Hardcastle, Beck, Chinyo, and Assenova (2003), the concessionaire retains the title of ownership during the concessionary period, which is normally between 10-50 years, after which the title of ownership is transferred back to the government. The following agreements are involved in a typical BOT agreement: concession agreement, loan/financing agreement, shareholders agreement, construction contract, supply contract, off-take agreement, operation and maintenance agreement.

\section{IMPLEMENTATION OF WAQF SUKUK: CASE STUDIES WaqfSukuk in Singapore}

The Singapore Waqf Sukuk was issued to develop a Waqf property to an Arab merchant named Shaikh Ali B Omar Aljunied. It was for the development of 104 serviced-apartments, a mosque and a 6-storey commercial complex, the 
cost of which was approximated to be $\$ 35$ million. The structure was based on musharakah. At the initial stage musharakah venture was entered into by 3 parties, that is, the Waqf, Baitulmal and Warees (wholly-owned subsidiary of MUIS). The Waqf contributed the land and capital, the baitulmal provided \$35 million from investors and Warees provided a nominal amount along with their expertise. The second stage involves a leasing contract agreement that was entered between the Special Purpose Vehicle (SPV) and Ascott International Pte. Ltd. who agrees to lease the property for a period of 10 years thus ensuring a steady flow of income as return to the investors.

The fact that it is a Musharaka venture means profit will shared in accordance with the proportion of capital invested by the 3 parties. As a result of the success recorded by this Sukuk, MUIS was awarded Mohammad Bin Rashid Al Makhtoum Islamic Finance Award in the category of Regional Continuing Contribution to Islamic Finance in that particular year. This innovative financing structure has resulted in increasing the revenue generated by the property from an annual rental of $\$ 19,000$ per annum to a gross income of $\$ 5.3$ million in 2006. Figure 1 illustrates the relationship among the stakeholders in the Musharaka WaqfSukuk.

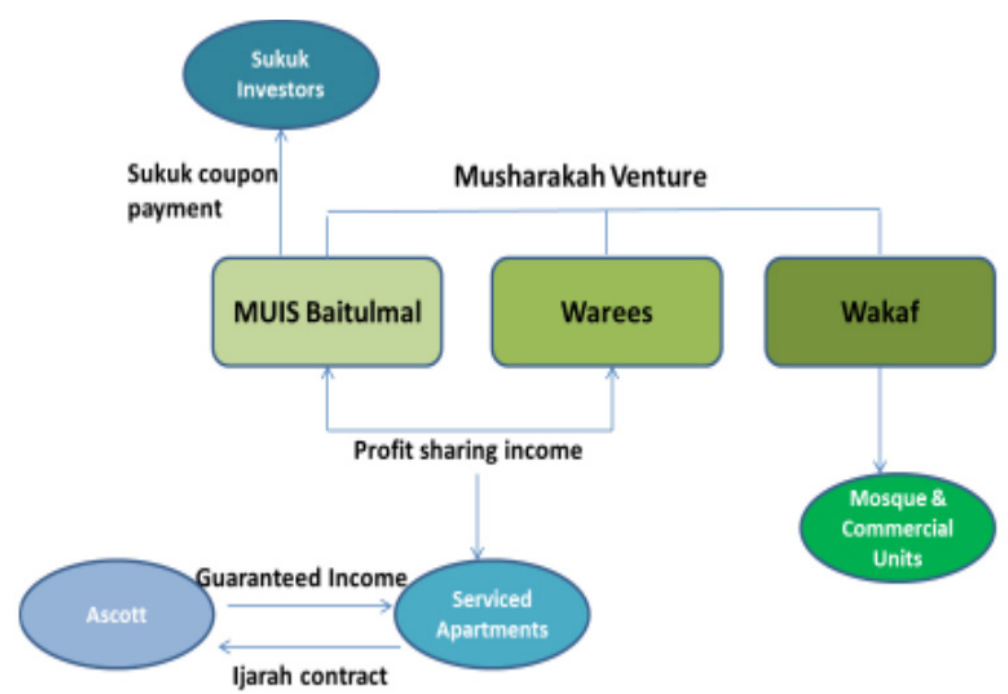

Figure 1: Structure of Singapore Musharaka Waqf Sukuk

Source: Adapted from Zain and Sori (2017)

\section{The Saudi Arabia Sukuk Al-intifa'a}

The Saudi was a Sukuk al intifa'a issued in 2000 at the Holy City of Makkah. King Abdul Azis Waqf (KAAW) was the custodian of the Waqf (Nazir). 
IQTISHADIA

12,1

This building Hotel accommodations with room spaces ranging from low prices up to royal suites. To be able to finance the project, Munshaat issued US \$ 390 million Sukuk Al-intifa'a (timeshare bond) for 24 years. This usufruct right will be divided into weekly time shares. Investors who bought this Sukuk are able to rent a space for a specific time or sub-leased their space to others. Munshaat will then gain the profit from the rent rate difference between the rate received from Sukuk holders and the rate paid to Binladin Group. Munshaat estimates 26\% rate of return on this investment (Ahmed, 2004). Figure 2 outlines the structure of the Sukuk al-intifa'a.

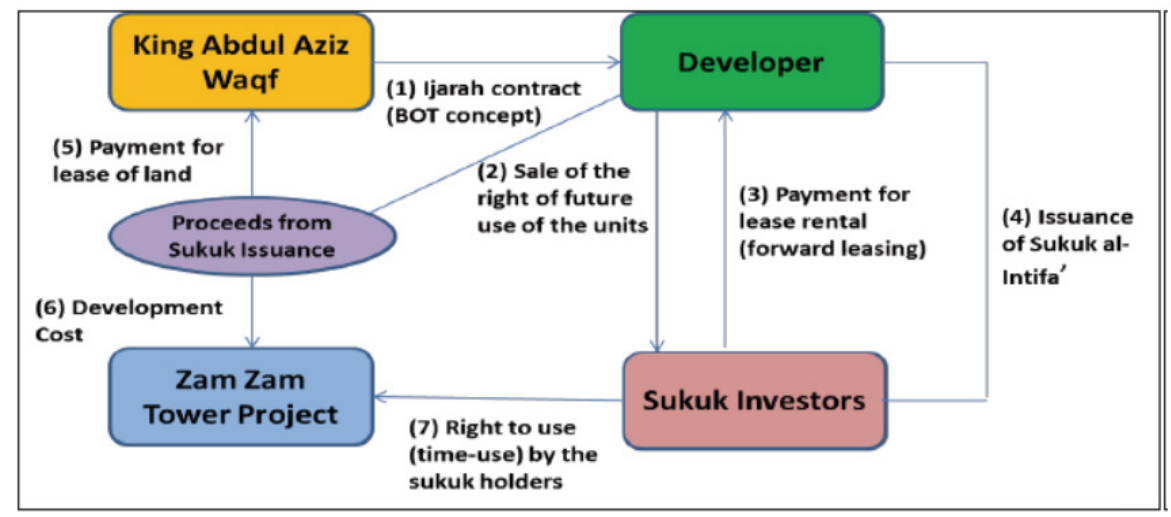

Figure 2: Saudi Arabia Sukuk al intifa'a

Source: Adapted from Zain and Sori (2017)

\section{MODEL}

The proposed model begins with the Waqf institution which could either be an Islamic charitable Foundation or a waqf board under the state that has landed property or undeveloped land under its control. The purpose of the Waqf linked sukuk is to redesign an obsolete building that happens to be located in a choicest area or to develop an undeveloped land. The property or land will be given out on a long lease (Hukr) of say 20 years to a developer who will float an SPV for the purpose of mobilizing funds through an investment sukuk to develop the land into commercial shops based on principle of buildoperate-transfer contract. The SPV appoints a property developer or company 
to develop and manage the property. When developed, rent received will be remitted back to the investors up to the end of the lease period between the Waqf Foundation and the property developer through the SPV. On maturity of the contract, that is, 20 years, the Waqf Foundation will take possession of the developed property and will continue receiving the rent.

The working of the model is explained as follows:

i) The Waqf administrator/Charity enters into an Ijarah contract (with BOT concept) with the property development company who receives the Waqf land on long term rent (Hikr), develops it into modern property for renting to businesses and operates/ manages it. After the agreed period, the newly developed property is handed over to the Waqf/Charity.

ii) The Property Development Company establishes (Special Purpose Vehicle (SPV) to raise funds.

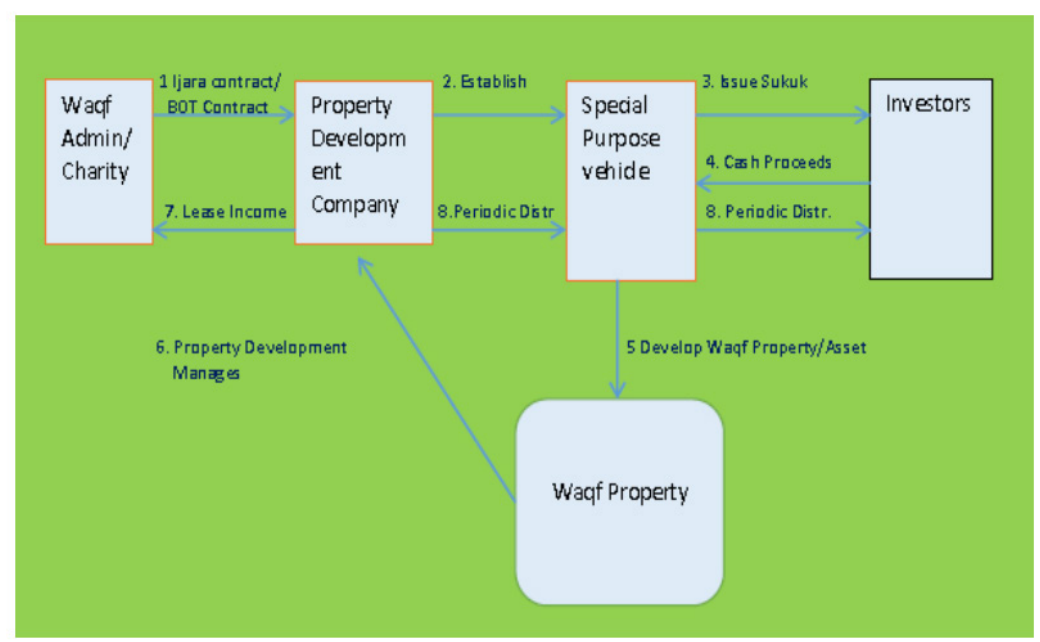

Figure 3: The Proposed Waqf-Based Model

Source: Authors Intuition

iii) SPV issues Sukuk for the development of Waqf properties/assets.

iv) Investors provide the cash for the development of the land.

v) SPV then proceeds with the agreed development on the Waqf properties/assets.

vi) The SPV appoints a property development company to manage the Waqf properties/assets and charges a commission for its service. The agreed lessor (customer) of the properties enters into a forward leasing with the Property Development Company.
Sukuk:

A Veritable

Tool

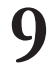


IQTISHADIA

12,1

vii) The Waqf/Charity receives the agreed lease income and distributes it to beneficiaries annually.

viii) The remaining income from the development of Waqf properties/ assets is shared with the investors based on the agreed amount annually for an agreed period.

\section{CONCLUSION AND RECOMMENDATIONS}

Effective management of multifarious Waqf assets in Nigeria is marred by a number of challenges. The nature of the assets which largely are on the form of traditional Waqf properties; land, houses, mosques, orphanages, hospitals, shops, etc., provide little or no room for generating much revenue in themselves. This is coupled with the fact that the Waqf administrators (Nazirs) are lacking in knowledge and skills in conventional art of Islamic fund management. Accordingly, the paper seeks to unveil how Waqf-based Sukuk could be used to attain effective development as well as management of these classes of Waqf assets. Using a non-experimental, deductive-analytical approach in its investigation, the paper in the light of experiences in Singapore and Saudi Arabia, develops a Waqf-based Sukuk (ijarah) framework for fund mobilization for development of Waqf properties in Nigeria.

It is hoped that stakeholders comprising religious scholars, awqaf authorities, academicians, practitioners, developers, financial institutions, would collaborate towards actualizing this model towards development of waqf locally in the light of existing globally best practices.

\section{References}

Akintoye, A.S and Macleod, M.J (2003). Risk Analysis and Management in Construction. International Journal of Project Management.Vol.15 No .1 pp. 31-38.

Alhabshi, S. O. (2012). Wealth Planning and Management, International Center for Education in Islamic Finance, Kuala Lumpur, Malaysia.

Anwar A. P. and Muhammad Isa A. J. (2016). The Constraints of Malaysian Mutawalli in Developing Idle Waqf Lands. Proceedings of the 
Muktamar Waqf Iqlimi III, http://doi.org/10.13140/RG 2.2. 11520 84483 .

Sukuk:

A Veritable

Tool

Chege, L and Rwelamila P.D. (2000). Risk Management and Procurement Systems - An Imperative Approach. Proceedings of the CIB W92 Symposium, Santiago, Chile, April.

Dali, N.R.M, Zakaria, M. Z., Salleh, A.Z. Zainuddin, M.T. and Abdul Jalil, M.A. (2017). Waqf Sukuk - The Overview and Current Practices. Proceedings of the 4th Asean Waqf Seminar 2017. Universiti Sains Islam Malaysia (Usim)

Elasrag, H. (2017). Towards a New Role of the Institution of Waqf. Retrieved from https://mpra.ub.uni-muenchen.de/80513/

Ismail, R., D. Muljawan, M.R. Chalid, J. Kashoogie and S. Sastrosuwito (2015). Awqaf linked sukuk to support the economic development, Occasional Paper Series, Bank of Indonesia, OP/1/2015.

Lahsasna A. (2013). Family Waqf as a wealth Management tool, Paper presented at the Islamic wealth management seminar. Kuala Lumpur Malaysia.

Maghbub, M.A and A.S Alhajam (2018). Proposal Framework of Waqf Institutions' Governance and Its Economic and Social Implications, International Journal of Islamic Economics and Finance Studies, vol. 4(2), pp. 6-16.

Marzuki, M. Shahmi, M. U., Ismail A. G. and Emborg Z. (2012). Tracking Poverty: A look at Cash Waqf

Musari, K. (2016) Waqf-Sukuk, Enhancing the Islamic Finance for Economic Sustainability in Higher Education Institutions. A paper presented at the 2nd World Islamic University Leaders' Summit 2016 (WICULS 2016) at Malaysia. Retrieved from https://www.researchgate.net/ publication $/ 321483883$

Oubdi, L. and Raghibi, A. (2018) Sukuk-waqf: The Islamic Solution for Public Finance Deficits. EJIF - European Journal of Islamic Finance, No. 9; Munich Personal RePEc Archive. Retrieved from https://mpra. ub.uni-muenchen.de/85629/

Tahir, M, AbdulHamid, M. I. and Ismail O. (2005). An Ideal Financial Mechanism for the Development of Waqf Properties in Malaysia, pp. 1-68.

Zain, N. and Sori Z. M. (2017). An exploratory study on Ijarah Sri Sukuk for the Development of Waqf Properties/Assets in Malaysia. INCEIF Kuala Lumpur Malaysia. 